\title{
Influence of EU and International Institutions in Albanian Higher Education
}

\author{
Mphil. Elona Mehmeti \\ Department: Political Science Department \\ Albanian University
}

\begin{abstract}
One of the problems identified in Albanian Higher Education (at least in the last 20 years ) is the bond that exists between the mission that it has and the vision that it is presented in development policies, reforms, strategies and legal framework from which derive these strategies. Is easily perceptible that proper studies on Higher Education are lacking, this fact often leads to the repetition of errors on higher education reform. On the other hand, the lack of clarity has led to the loss of many opportunities on the possibilities of internationalization of Albanian Higher Education, especially regarding the benefits of European funds from EU. The Study on the mission and vision of the Albanian higher education is part of a scientific research which will be presented at the $\mathrm{PhD}$ defense, however this article aim to present some of the findings and analyzes related to the vision of Albanian in Higher Education. The years that are compared are those on the Bologna agreement implementation, 2007 - 2013, which referring to the analysis results are years with a clearer vision in its Top Down enforcement policies.
\end{abstract}

Keywords: Mission and vision of Higher Education, Bologna Agreement, internalization , European funds

\section{Introduction}

The obvious lack of studies on the role that reforms in higher education had since the liberalization of higher education has often lead to confused strategies, which had consequences for the progress and development of higher education in the Albania.

This presentation is part of a broader study of the doctoral level that is expected to be introduced in the summer of 2017 which focuses on the mission and vision in Albanian higher education, and how this vision which comes to us through strategies and reforms translates into higher education and more specifically to the institutions representing higher education such as universities in Albania.

The presentation starts from a hypothesis being investigated in different historical phases of the development of Albanian Higher Education. One of the most important is the Bologna Agreement Implementation Phase. This phase was the clearest on the vision and mission that higher education had. The focus of this paper will be on investment in higher education through the Tempus and Erasmus Plus project, data are refreshed and taken into official form by the European Commission

\section{Higher Education in Post-Totalitarian Countries}

The collapse of the Soviet Union was one of the greatest revolutions in the world after the First and Second World Wars

After the developments of 1989, 31 countries left the "protective tent" of the Soviet Union and began the creation of states no longer totalitarian and communist, but with a kind of fragile democratic structure and with a democratic election. These countries oriented their economies toward market economy. 
One of the effects of the first democratic developments in these countries, was restructuring the public education system in order to ensure the necessary transformation to which the country needed, while also prepare students and professionals for the country's new leadership.

As Paola Sablof quotes in her study and Renáta Kralikova in her doctoral thesis of the three university models in the Slovakia, Romania and Lithuania, despite the fact that these countries came out of the same totalitarian system, their journey after the collapse of the system was different.

One of the reasons for the different adjustment is closely related with the inputs, as Kralikova concludes in her study, such as law, finance, massification, etc. While Paola Sabloff, in her book "Higher Education in Post-Communist world," explains that a special role in this new diversity created after the fall of the totalitarian regime, had culture, language and the whole social dimension that these countries had (Sabloff, 1999).

Paola Sabloff presents a detailed study of how the countries that emerged from totalitarian systems adapted to the new dimension, seen from an institutional perspective. In this context she investigated not only the university models, but also the most representative public institutions in the country. This study is very valuable to "see under the microscope" what happens at the institutional level. But it goes beyond the objectives of this research. Perhaps in the future it would be appropriate to be realized in Albania such a comparative study.

In this context, our focus will remain in the Western Balkans, which unfortunately has not been the subject of systematic research. As stated by Pavel Zgaga, one of the leading experts on higher education in the region, there are two reasons:

First, because there is a lack of information and data for the region, and secondly, there is a lack of previous research in the field of higher education (Zgaga, P., and others, 2013, p. 15).

\subsection{Brief historical overview and information about higher education in the Western Balkans}

Over the past two decades, the Western Balkan countries have developed their higher education systems in different ways. Resent conflicts and an economic and slow institutional transition have also affected the Western Balkan countries.

In all the Western Balkan countries, regardless of the extent and opportunities they have, there is a clear trend to get opinions from outside. Politic always copies and referred as a success alternative the experience of the western countries, but often also get models that come out of continental Europe. As an example in this case is the Albanian higher education reform which is inspired from an English model of higher education.

If we make a comparison with their Western European counterparts, universities in the Western Balkans are relatively young. Higher education in this region was mainly developed after the Second World War. Exceptions here are universities of countries such as Croatia and Serbia. University of Zagreb was founded in 1874, although a previous institution dates back to 1669 . On the other hand, the Belgrade University was founded in 1905, the previous institution dating back to 1808 (Šoljan, 1991).

\subsection{Communist legacy and developments of the $90 \mathrm{~s}$}

Seven Western Balkan countries have been part of a federal system until the early 1990s, in what was then called the "Socialist Federal Republic of Yugoslavia". Since 40 years, and follows in the 50's, Yugoslavia "maneuvered" for its existence between East and West and was not part of the Warsaw Pact or NATO. Precisely this position provided favorable relationship between two sides (east and west) during the Cold War, as well as good commercial and credit relations (in particular, loans that came from the West).

Albania, on the other hand, was ruled until 1990 by a harsh communist regime of the line set by Enver Hoxha. The country was very isolated economically and politically, in the late 20th century, it was one of the poorest countries in Europe. 
The end of the Cold War and the fall of the Berlin Wall, also meant the end of communism in the Western Balkans. The former Yugoslavia was marked by a series of wars in the territories of Bosnia and Herzegovina, Croatia and Slovenia, the last of which ended in late 1995; (2) a peaceful independence of Macedonia in the early 90s; (3) an armed conflict in Kosovo between Serbian forces (army, police and paramilitary forces) and the Kosovo Liberation Army, followed by the NATO intervention and the withdrawal of Serbian forces from Kosovo in the summer of 1999, which in 2008 it culminated in the Kosovo independence declaration from Serbia; and (4) the independence referendum in Montenegro in 2006.

In most of the countries that emerged from the former Yugoslavia, the democratization process was lagging behind other Central European countries, including Slovenia. According to Freedom House democracy index, which uses four criteria to assess the democratic deficit of a country, of all Western Balkan countries marked as flawed democracies or hybrid regimes.

The '90s were a period without stability in Albania, both politically and economically. This included several economic crises (mostly in 1992 and the end of 1996), as well as an armed rebellion in 1997. Albania and Macedonia were also affected by the conflict in Kosovo, given that a significant number the Albanians from Kosovo found refuge there, especially in 1998 and 1999 .

While Macedonia also went through a period of internal ethnic conflict in 2001, all these developments slowed and, in some cases, completely blocked the political and economic transition, as well as relations with the European Union (Freyburg \& Richter, 2010; Subotid, 2010, 2011), One of the main objectives of the EU in the Western Balkan was the democratization of the countries and then the opening of negotiation process (Dolenec, 2008, p. 23).

Such a complex political, economic and social situation in the Western Balkans inevitably affected the development of policies in education

Some of the former Yugoslavia countries experiences in the ' 90 s a form of international isolation (caused again by internal factors and by external factors), with very limited interaction with the international academic community and an almost nonexistent relationship with European structures of higher education, thereby not having any track approach to European programs of higher education or participation in joint research. This was also the time where there was no development, especially in countries with more conflicts such as Bosnia and Herzegovina and Macedonia.

In Croatia there have been efforts to undertake reforms, though with great difficulty in terms of implementation (see Orosz, 2008). In Serbia, the regime focused mainly on reducing the role of democratization that had higher education in society and why, after a series of student protests and small academic strikes in Serbia, it was presented at the 1998 regulation, which abolish institutional autonomy and academic freedom.

In Albania, although a new law on education, which included higher education was adopted in 1994, most of the reforms had to be postponed due to the internal political instability.

In Montenegro, there have been legislative changes in 1992 and 1994, but there was no other significant development during the $90 \mathrm{~s}$.

Kosovo has been and continue to be in the under-review period, the higher education system is dual. By the late 90 s this duality is expressed by the Serbian official system of higher education and an Albanian informal system of higher education (bearing in mind that Albanian students and professors were expelled from the Serb-controlled universities in Kosovo in the early 90s). From 1999 onwards, the duality is present again in what some would argue two be a parallel system - one in northern Kosovo, where there are still a Serb majority and the other in the rest of Kosovo.

This duality, along with changes in terms of positions on Kosovo's statehood, also affects the perception of whether institutions of higher education in Kosovo can participate in the Bologna process or not (see below). 
This conflict situation in the region, implicates difficult diplomatic relations among the countries in the region, and complicates the relationships in the European Union. Regardless, this situation affects the institution relations among universities.

The picture that appeared was not very optimistic. In the ' 90 s there was a large, mass higher education in these countries, but without an investment in infrastructure, and in academic staff. While other challenges include a "brain drain", which was not only in the early 90 s, but continued for a long time, and it is present in some countries even now.

\section{The Bologna Agreement - the beginning of a new era!}

History does not constitute an interest for the technocrats who design this great project of higher education and this because they were busy to catch the rhythm of the United States in education. However, historical and political context where this agreement was born, it is very important to understand the Bologna complexity.

There is no need to return in the 1088 in Bologna to have a clear understanding of the agreement. Nevertheless, some aspects of the historical part would be necessary to understand the whole process.

An important detail is that the university in Europe took place within the modern state, serving its needs to train the country's elite.

Until the official development of the European market in 1992, there were few developments in Europe that will make us think about a European system or less to a European system of higher education.

Moreover, institutions were incompatible, they had different programs and qualifications.

Yann Lebau, in his analysis of the French system of higher education, gives us a good example of French universities attempts by one side to bring master programs in English, and by the other the struggle of an elite which desperately demanded ways to balance this great influence of English language in university institutions.

Another historical important fact to emphasize is, at the end of 1980s and early 1990s, many of the countries that signed the Bologna agreement in the 2000s belonged to former bloc communist countries. Higher Education systems of these countries did not flourished during these 20 years in the democracy. On the other side those educational systems in the periphery of Europe during this decade were also under the pressure of massivisation of higher education in an extreme shortage of funds.

While the World Bank suggested Sub-Saharan African Countries to spent not less than 1,000 US per student, in order to have quality in higher education, at least four of the former communist countries, such as Bulgaria, Georgia, Macedonia Russia spent much less. Baltic countries, Estonia and Latvia, were somewhere in the margins of this amount per student. Although this might be true, it is important to underline that in this analyses is not included Turkey, because the country has a complex relationship with Europe.

Despite this difficult mission in creating the European Area of Higher Education there are also optimistic views like those expressed by Zgaga (Zgaga, 2003), that the diversity of the countries that joined Bologna will bring greater dynamism in the European higher education. However, someone can easily think that if there are a lot of dynamic it would compromise the entire foundation upon which this agreement arose.

\subsection{Periphery of Europe and their higher education}

What man of the researchers agree is that the Bologna process has been implemented as a process, which comes from the top - down and there is no center from which it derives. Moreover, it is noted already that Bologna remains a process of continuous negotiation. In the process you asked universities to be productive as if they offer a service in the market, in 
this case the process puts intellectuals under a very difficult position, where academic freedom of university life is a privilege of the few.

Recalling Kant at the conflict of the faculties .... we can accept that we would be very lucky if the university would be allowed to seek their economic irresponsibility towards the search for truth and knowledge, under the pressure of a Europe of this century were more and more there is a stress in the provision of services than knowledge transmitting.

However, this is only one piece of Europe on the other part it is the Periphery of Europe as Tomusk named it in his book Creating the Higher Education Area, where there is more enthusiasm because these countries see the Bologna Process as a part of their integration in the EU.

Thus, in the last decade, higher education has emerged as a key sector in social and economic transition that developed in the Eastern Europe countries and the former Soviet Union countries.

The concern of these companies is focused in several elements:

First, societies of these countries suffered a significant loss of their intellectual resources, as a result of disintegration at the national level, political reasons, the brain drain and reconstruction of the market;

Secondly, all these countries have seen higher education as a way for recruitment young people to prepare them to enter in politic;

Thirdly, higher education is increasingly seen as a force which helps companies, which are in transition to approach powerful and richer countries.

In those countries that have gone through a difficult economic and financial situation, lack of infrastructure and low salaries in the higher education system have also neglected the development of higher education even when basic services do not seem possible.

Despite the attention that governments had since the fall of communism, these countries have experiences a failure in the reform because they have been prevented or simply ignored.

Consequently, higher education in the region still has many critics, financial restrictions, structure issues and questions related to the function and identity. On the other hand, there are always these policy makers, experts, analysts and public discussions, which are imbued with globalism, by imposing policies from outside, without a local assessment of how global solutions can be imported into the local reality.

\subsection{How important is Europe to the periphery of Europe?}

Higher education is not an isolated island and this is an expression that fits very well to the Western Balkan countries.

Higher education, in the six Western Balkan countries is significantly influenced by the Bologna Agreement and the Lisbon Strategy, both these initiatives are more closely linked to what is discussed today as European Area of Knowledge.

All higher education systems in the Western Balkan countries are now part of the Bologna Agreement, in particular those of Kosovo. In this context, all the Western Balkan countries have ambitions for their involvement in the EU. Some of them are already part of the European Union, such as, Croatia for example, while others are considered as potential credible member to join soon this community (Vachudova, 2009).

Despite the two agreements are very important, we need to acknowledge that each of them applies to different things. For example, the Lisbon Strategy is a nationwide process with several instruments, which are developed as is the case:

a. development of procedures for recognition of qualifications in what are called regulated professions (Beerkens, 2008); 
b. or the fact that formal decisions are only recommendations (for example, as was the case with the recommendations of the Council and the Parliament on qualifications);

c. development of instruments and allocating funds for a number of joint projects, such as, lifelong learning for example, and programs related to research.

These programs, developed under the roof of the Lisbon strategy, have had a substantial value to the Western Balkan countries, compared with not very favorable economic situation that these countries experienced, where, as a result, such programs helped the university and different development projects.

From another perspective, the Bologna Process does not cover or have no administrative capacity and there is no funding for the process, which will facilitate the implementation of the declaration.

This initiative started as a voluntary initiative, which had a control group, it is the Bologna Follow-Up Group (BFUG). The European Commission is a permanent member of this group, while other European organizations have observer status.

Given such an initiative is without center and without a budget or funding, and where its members are countries that have voluntarily signed to be part, the Bologna Process is an initiative, which sets its own objectives. By nature, this process is more detailed in relation to the Lisbon Strategy, as it touches disciplines in particular by defining the structure, credits and duration.

Both processes are "target in motion," according to Gornitzka and Kehm, and this precisely because the policy contents and instruments vary, also stakeholders at European level can often vary (both individually and collectively). Moreover, the status of the Western Balkan countries in relation to the EU is not fixed, since some countries are at the candidate stage and others such as Croatia are already full-fledged member.

Precisely such situations and these changes make each country to the a different position in relation to the Bologna process.

To provide a summary the Western Balkan countries, because of their official position with respect to integration, have very little influence at European level. This powerlessness is also identified in other parts of higher education. In such conditions, having no direct and clear guidelines, each state was free to interpret part of the process as they understood it.

\section{The role of the Bologna Agreement in Albania}

As mentioned above, the Bologna Agreement was an agreement that was built as a union of free wills of countries that have signed it. Each of the states was free to interpret parts of the process.

Despite the fact that the agreement was implemented partially in some of the programs, it was the academic year 20052006 and later with the emergence of the new law no. 9741, year 2007, that all universities implemented the application of the system of credits that would make more easy the student mobility as well as reform all the university curriculum.

All these elements made it possible for the structural adjustment of university curricula to set a benchmark so the recognition policy and credits transferee system would be more easy.

In recent years, Albania benefited and continued to the present in the European Higher Education projects such as Tempus and Erasmus Mundus and Erasmus Plus.

The table below shows data after the Bologna Agreement implement up to 2013 on the projects that Western Balkan countries participated or was a coordinator. 
Table no. 1 Information about European Projects in the Wester Balkan Countries

\begin{tabular}{|c|c|c|c|c|c|c|c|c|c|c|c|c|c|c|}
\hline Years & 2008 & & 200 & & 2010 & & 201 & & 201 & & 201 & & 2008 & 2013 \\
\hline Counties & 茥旁 & $\frac{0}{\frac{\alpha}{\alpha}}$ & $\begin{array}{l}\frac{\alpha}{\alpha} \\
\frac{\alpha}{0} \\
\frac{0}{\alpha}\end{array}$ & 言 & $\begin{array}{l}\frac{\alpha}{\alpha} \\
\frac{\alpha}{\alpha} \\
\frac{\alpha}{\alpha}\end{array}$ & 言 & $\begin{array}{l}\frac{\alpha}{\alpha} \\
\frac{\alpha}{\frac{\alpha}{\alpha}} \\
\frac{0}{\alpha}\end{array}$ & $\begin{array}{l}\frac{\alpha}{\alpha} \\
\frac{\alpha}{\alpha} \\
\frac{\alpha}{\frac{\alpha}{\alpha}}\end{array}$ & $\frac{n}{\frac{n}{\alpha}}$ & $\begin{array}{l}\frac{\alpha}{\alpha} \\
\frac{\alpha}{\alpha} \\
\frac{\alpha}{\alpha}\end{array}$ & $\frac{0}{\frac{0}{\alpha}}$ & $\begin{array}{l}\frac{\alpha}{\alpha} \\
\frac{\alpha}{\frac{\alpha}{\alpha}} \\
\frac{\alpha}{\alpha}\end{array}$ & $\begin{array}{l}\frac{\alpha}{\alpha} \\
\frac{\alpha}{\frac{\alpha}{\alpha}} \\
\frac{\alpha}{<}\end{array}$ & $\frac{0}{\frac{0}{\alpha}}$ \\
\hline Albania & 7 & 0 & 3 & 0 & 5 & 0 & 5 & 0 & 3 & 0 & 9 & 1 & 32 & 1 \\
\hline $\begin{array}{l}\text { Bosnia - } \\
\text { Hercegobina }\end{array}$ & 9 & 2 & 7 & 0 & 6 & 0 & 8 & 2 & 13 & 1 & 10 & 0 & 53 & 5 \\
\hline Croatia** & 9 & 2 & 6 & 1 & & & & & & & & & 15 & 3 \\
\hline Macedonia & 16 & 1 & 10 & 2 & 7 & 0 & & & & & & & 33 & 3 \\
\hline Kosovo*** & 6 & 1 & 6 & 1 & 5 & 1 & 5 & 0 & 6 & 1 & 11 & 2 & 39 & 6 \\
\hline Montenegro & 7 & 0 & 4 & 0 & 4 & 2 & 7 & 0 & 8 & 2 & 11 & 3 & 41 & 7 \\
\hline Serbia & 17 & 7 & 13 & 6 & 12 & 8 & 11 & 6 & 13 & 8 & 18 & 13 & 84 & 48 \\
\hline TOTAL & 27 & 13 & 25 & 10 & 21 & 11 & 17 & 8 & 24 & 12 & 35 & 19 & 149 & 73 \\
\hline
\end{tabular}

*Country figures cannot be added, as several countries can be involved in the same project

** In 2013, Croatia was involved in 7 selected projects (2 as coordinator), but in the role of EU Member State, not

as Partner Country

${ }^{* * *}$ This designation is without prejudice to positions on status, and is

in line with UNSCR 1244 and the ICJ Opinion on the Kosovo

declaration of independence.

APP $/$ PAR $=$ Number of selected projects in

which the country's institutions are coordinator

or partner

APP $=$ Number of selected projects in which the country's institutions are

coordinator

As noted in 2008, Albania seems to be in disadvantaged position in relation to projects compared with other Western Balkan countries, but ongoing commitment of Albania in these projects has not experienced an increase as may be the case in other countries of the Western Balkans.

Today in relation to Western Balkan Countries, Serbia seems to to be involved in more projects simultaneously and at the same time be a coordinator and a partner.

\section{Conclusions}

If there is an increase in higher education policy, is expected to have an increased clarity in the perception of the university mission." In this context, if there is more clarity is expected to have more projects developed in higher education.

As noted in the context of the table no. 1 it is noticeable a significant decrease in the project participation Tempus Albania compared with the neighbor countries like Bosnia and Serbia. During the years 2008-2013 Albania was working on a new higher education reform that targeted financing strategy on higher education. This reform never took place and brought to higher education a confusion on the direction that higher education would follow, by decreasing even more the participation of Albanian Higher Education in international projects. 


\section{References}

[1] Beerkens, Eric (2008). The Emergence and Institutionalisation of the European Higher Education and Research Area. European Journal of Education, 43(4): $p$ 407-425

[2] Dolenec, D. (2008). Europeanization as a Democratising Force in Postcommunist Europe: Croatia in Comparative Perspective. Politicka misao, XLV(5), 23-46.

[3] Freyburg, T., and Richter, S. (2010). "National identity matters: the limited impact of EU political conditionality in the Western Balkans." Journal of European Public Policy, 17(2), 263-281.

[4] Gornitzka and Kehn (2008) In pursuit of excellence? Discursive patterns in European higher education research, Springer

[5] Gornitzka, Ase, and Peter Maassen (2011). "Global Pressures and Local Realities. European Universities at a Crossroads." In . St. Antony's College European Studies Centre, University of Oxford.

[6] Magna Carta e universitetit, Bolonjë, 18 shtator 1988. SEE ECN.

[7] Sabloff, P. (1999) Higher Education in the Post-Communist World, A case study of Eight Universities, New York and London: Garland Publishing.

[8] Tomus, V ( 2006) Creating the European Area of Higher Education: Voices from the Periphery: Springer

[9] Vachudova, M ( 2009) Corruption and Compliance in the EU's Post-Communist Members and Candidates, Journal of Common Market Studies.

[10] Zgaga, P.; Manja, K., Janja K., Klemen, M., Igor R., Vedran, J.: Higher education in the Western Balkans: Reforms, developments, trends,University of Lubjana \& Cepes 2013. 